\title{
Social Capital in Mangrove Utilization for Silvofishery: Case Study in Kutai National Park, Indonesia
}

\section{Iin Sumbada Sulistyorini ${ }^{1^{*}}$, Erny Poedjirahajoe ${ }^{2}$, Lies Rahayu Wijayanti Faida ${ }^{2}$, Ris Hadi Purwanto ${ }^{3}$}

\author{
${ }^{1}$ Forest Resources Conservation, Forestry of Study Program, High School of Agriculture (STIPER), \\ J1. Soekarno Hatta 1 Sanggatta Utara, Indonesia, 75611 \\ ${ }^{2}$ Department of Forest Resources Conservation Faculty of Forestry, Gadjah Mada University, \\ J1. Agro 1 Bulaksumur, Sleman Yogyakarta, Indonesia 55281 \\ ${ }^{3}$ Department of Forest Management Faculty of Forestry, Gadjah Mada University, \\ Jl. Agro 1 Bulaksumur, Sleman Yogyakarta, Indonesia 55281
}

Received February 21, 2018/Accepted May 25, 2018

\begin{abstract}
Social capital has an important role in mangrove management on conservation areas. Utilization of mangrove forest with silvofishery system can be an alternative developed for the community around the conservation areas. The purpose of this research is to know the strength of social capital in supporting the utilization of mangrove for silvofishery. This research adopted Social Capital Assessment Tool method and data analysis with Partial Least Square-Structural Equation Modeling. The results of the study found that there were several elements of social capital in five study villages that have not supported silvofishery in Kutai National Park (KNP), East Kalimantan, Indonesia. The overall analysis of the respondents showed that there were five elements of social capital have significant effect on silvofishery. The other two elements were insignificant and should be of particular concern to be improved, i.e. social networks and social norms. Indicators to be aware of were the increased knowledge of communities on park-related regulations, increased involvement of individuals in the community, and the strengthening of public figures who can be role models for the community. Mangrove forest of KNP should be kept as conservation area, but it should still pay attention to the socio-economic conditions of the surrounding community. The strength of social capital is expected to realize conservation-based economic development.
\end{abstract}

Keywords: community, conservation, socio-economic, mangrove, East Kalimantan

*Correspondence author, email: iinsumbada@stiperkutim.ac.id

\section{Introduction}

The surrounding community can not be separated in the management of a national park. According to the Government Regulation of the Republic of Indonesia Numbered 108 of 2015 has defined that the National Park as a Natural Conservation Area (NCA) ecologically having a native ecosystem, managed by a zoning system that can be utilized for research, science, education, recreation, tourism, and supporting cultivation. Law of the Republic of Indonesia (UU RI) Numbered 1 Year 2014 on the Management of Coastal Areas and Small Islands, has confirmed that coastal area management is aimed at improving people's welfare. Brander et al. (2012) explains that mangroves in Southeast Asia provide valuable ecosystem services for human wellbeing. Walters (2004) concluded that local communities are effective maintainers of mangrove forest resources.

The mangrove productivity of $350-500$ gram C m$^{-2} \mathrm{yr}^{-1}$ is characteristic of mangrove net production in coastal waters and a broad proportion of coastline in the tropics (Mann
1982). The mangrove ecosystem is one of several high productivity ecosystems that produce food sources for most of the coastal biota (Budihastuti et al. 2012). Mangrove forests provide valuable ecosystem services for coastal communities, tourist attractions, nature conservation, education and research. However, this ecosystem is fragile because it is very sensitive to environmental changes (Eddy et al.2016).

Conversion of mangroves into ponds is one of the largest contributors to the destruction of mangrove forests globally (Kunarso et al. 2015). Mangrove in Kalimantan in 1989 has an area of about 1 million ha more, then in 2009 decreased to 638,283 ha (Ilman et al. 2011). The mangrove forest of Kutai National Park (KNP) continues to be under increasing pressure due to increased human activities both for settlement, agriculture, and other activities (Bismark \& Iskandar 2002; Sulistyorini et al. 2017). The distribution of KNP mangrove forests undergoing conversion is caused by the lack of public knowledge about the status of the area, and 
the settlement of KNP coastal populations generally located close to rivers and creeks such as Muara Sangatta, Lombok and Sangkima, thus increasing accessibility and community land clearing activities (Budiarsa \& Rizal 2013). Nearly 23\% of the KNP mangrove forest is degraded due to land conversion and destructive utilization. So it is necessary to find a management concept that can maintain the preservation of mangrove ecosystems, but also consider the sustainability of local communities (Wijaya 2011).

Poedjirahajoe (2011) explained, one of the utilization of mangrove ecosystem to increase public income is silvofishery. According Purwiyanto and Agustriani (2014), one of the efforts to maintain the mangrove area is to conduct silvofishery system. Poedjirahajoe (2015) explained the ecologically silvofishery pattern ponds get a high supply of organic material from mangrove forests, resulting in higher production compared to conventional ponds. Purwiyanto and Agustriani (2014) conducted a study in South Sembilang National Park indicating that mangrove forest is very useful for aquaculture activities because of its ability to absorb nutrient pollutants. Sulistyorini et al. (2017) stated that the density of mangrove vegetation, temperature and thickness of mud in KNP mangrove forest is very suitable for silvofishery development.

Research on mangrove has increased exponentially in the last 50 years (Lee et al. 2014). Assessment of the status of mangrove forests is essential for better conservation planning and management (Schmitt \& Duke 2015). Mangrove mangrove management can not be separated from the participation of the surrounding community (Sayektiningsih \& Gunawan 2012). Communities should be the main actors in sustainable mangrove management (Qurniati et al. 2017). Sustainable mangrove forest management requires social capital (Juita et al. 2016). Social capital can be defined as the ability of people to work together to achieve common goals within various groups (Fukuyama 2000). Social capital is the ability of people to associate with each other and then become a very important force not only for economic life but also for every other aspect of social existence (Burt 1992). Social capital also underlies the trust of social relations and shared understanding of environmental issues (Pretty \& Ward 2005). Based on the research on social capital in villages around the buffer zone, KNP states that the frequency of following the organization, the number of organizations that followed, and community participation in decision making is still relatively low. In general, the community's trust towards the local government (East Kutai Regency) is low (Oktadiyani et al. 2013). Communities in the village have characteristics similar to those in the coastal KNP, such as from a variety of ethnic, diverse work activities and most are migrants from outside the region such as from Sulawesi and Java Island.

Based on the above explanation it is necessary research about social capital that can be used as a guide in the management and preservation of mangrove forests better. This study aims to determine the socio-economic characteristics and social capital of society in the utilization of mangrove for silvofishery. The social capital elements to be observed in this research are trust, social network, social norm, community involvement, community awareness, and community attitude toward mangrove utilization for silvofishery. Grootaert and van Bastelaer (2001) stated that social capital cognitively refers to norms, values, beliefs, attitudes, and caring for others. Bhuiyan and Hans (2005) and Putnam (1993) explained social capital refers to features of social organization, such as trust, norms, and networks

\section{Methods}

Study site description Since 2001 the area of Kutai National Park is 198,296 ha, then in 2014 reduced to 192,709.6 ha. The change of area is because there are two sub-district of government administration areas (Teluk Pandan and Sangatta Selatan) in East Kutai Regency that the included of KNP area and converted into Other Use Areas $(\mathrm{APL}=$ Area Penggunaan Lain). In the APL there are several villages such as Teluk Pandan, Kandolo, Teluk Singkama, Sangkima, and Kelurahan Singa Geweh which occupy the coastal part of the KNP area and serve as the study area in this study (Figure 1). Communities in the five villages have a variety of activities or occupations such as ponds worker, fishermen, government employees, company employees and other businesses. The tribes in these villages also vary such as Bugis, Java, Kutai, Banjar and others. The study period starts from September-December 2017.

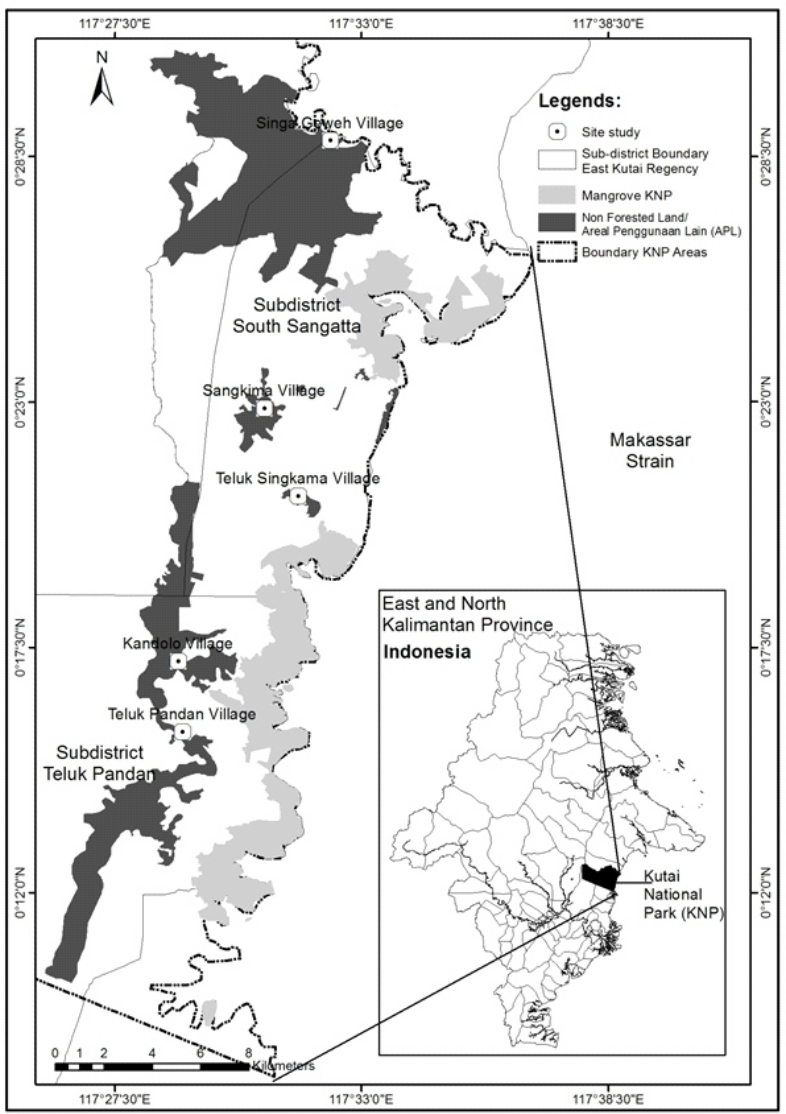

Figure 1 Study location in five villages in Kutai National Park, East Kutai Regency, East Kalimantan Province. 
Sampling and data collection Data collection was done by direct interview method to respondents with questionnaire guidance. The number of respondents is determined by the number of households (head of household) in each village. The total number of households in the study area is 6,033 . The minimum number of samples was based on the formulas introduced by Luck et al. (1987) that produced a minimum sample size of 252 households. In this study the number of samples already used is above the minimum amount of 530 households.

Social capital is highly contextual, and it is generally recommended that the choice of indicators be guided by local conditions and the extent of the unit of observation (e.g., indicators reflecting the social level of society may be less relevant at the national level (Grootaert \& van Bastelaer, 2001). The assessment of social capital consists of trust, community involvement and social cohesion (Barnes et al. 2015). Then in a study in KNP, the elements of social capital studied consisted of trust, participation in tissues, social norms, proactive actions, and environmental awareness were studied for the KNP buffer zone in Kabo Jaya, and Singa Gembara villages (Oktadiayani et al. 2013). Identification of social capital in this study adopted from some previous research.

Social capital has been conceptualized into three levels, i.e. micro, meso and macro levels. Measurement at the micro-level means measurement at the household or individual level (Grootaert et al. 2003). Micro-level measurement became the focus of the survey in this study and aimed at measuring the standard of living of households. Data collected included: formal education level (X1), and income level (X2). Social capital data include: trust (X3), networking (X4), social norms (X5), community involvement (X6), environmental awareness (X7), and attitude or public perception of the utilization of mangrove for silvofishery (Y1). This study used 8 latent variables with 35 indicators detailed in Table 1.

Data analysis This research uses qualitative and quantitative descriptive approach. According to Castellan (2010), quantitative studies can be conducted simultaneously with qualitative research, or qualitative with quantitative. The data processing of the questionnaire proceeds to the modified Social Capital Assessment Tool (SCAT). Social capital is categorized according to research needs into five levels, i.e. very low (45-81), low (82-118), moderate (119-155), high $(156-192)$ and very high $(193-225)$. The intervals of the five categories are 36 with a minimum value of 45 and a maximum of 225 .

Furthermore, to know the relationship of influence between veriabel element of social capital, factor analysis is done using Partial Least Square-Structural Equation Modeling (PLS-SEM) with the help of SmartPLS 3.2.7. PLS-SEM has been widely used in social sciences and was recently introduced into ecological studies (Peppler-Lisbach et al. 2015; Miguel et al. 2017). Research with small sample sizes and weak theoretical support can apply PLS-SEM to test causal relationships (Hair et al. 2014). Convergen validity, i.e. factor loading and Avarage Variance Extracted
(AVE) for this study is $>0.50$. Then the model evaluation for reliability is Composite Reliability $(\mathrm{CR})>0.7$. This model measures the path coefficient that depicts the greater the value the more influential. The hypothesis of this study was tested by considering the significance of the path, which is estimated through the value of t-test. The t-test for interpreting the strength of relations between variables is if the $\mathrm{t}$-Value $>\mathrm{t}$-table with $(\alpha) 0.05(\mathrm{t}$-table $=1.96)$, then the significant or supportive against other variables.

\section{Results and Discussion}

Characteristics of Socio-economic Respondents from five villages in the study area were households or heads of households. Male respondents or heads of households are about $67 \%$. This means that only a small percentage were women who can represent their families in providing information related to this research. Most of the respondents are under 40 years old who can be said to be productive age. Another social condition is very unfortunate, where about $50 \%$ of respondents only educated elementary school with income level below one million Indonesian Rupiah (IDR) per month. Low income levels are mostly owned by families of farmers or fishermen who, in principle, have no permanent employment. Side jobs are also present in some low-income respondents, but they do not dare to state with certainty the monthly income. Then respondents related to mangrove forests either as fishermen or tambak workers about $40 \%$ of the total number of respondents. Although these villages occupy coastal areas, there are not many people whose work is directly related to mangroves. Some respondents are working as government employees, company employees, selling in the market, farmers, and others. A summary of the general socio-economic conditions of the respondents is presented in Table 2.

Management of an area (natural resources) must be based on ecological and sociological concepts; if not, the management with all the activities undertaken will be able to collide with each other (interests) so that the dynamics of systems within the region will not take place properly (Tobing 2008). The management of national park should pay attention the social conditions and empowerment of the surrounding community (Siswanto 2017). Previously it has been mentioned that there are two sub-districts and some villages within the area of the KNP that some settlements are in coastal areas KNP. Population and land clearing issues at KNP including mangrove forests have been long-standing, so there needs to be a lot of research related to sociology of the community and finding community empowerment solutions without destroying the integrity of conservation areas. The KNP mangrove area is dominated by jungle zone (zona rimba) and only small area in Teluk Kaba is a utilization zone (zona pemanfaatan). Based on laws and regulations in Indonesia the jungle zone is a protected area and allowed activities are research, education, nature limited tourism, utilization of environmental services, and cultivation support activities. The jungle zones and core zones of national parks are not intended for residential and community plantations, but the facts on the ground, especially the KNP jungle zone, settlements, and gardens or 
Table 1 Description of latent variables and indicators

\begin{tabular}{|c|c|c|}
\hline Latent variable & Indicator & \\
\hline Education level (X1) & & $\mathrm{X} 11$ \\
\hline Income level (X2) & & $\mathrm{X} 21$ \\
\hline \multirow{6}{*}{ Trust (X3) } & - KNP management unit & $\mathrm{X} 31$ \\
\hline & - Local governments & $\mathrm{X} 32$ \\
\hline & - Social norms/rule traditions & X33 \\
\hline & - Public figures in local society & $\mathrm{X} 34$ \\
\hline & - Local communities & $\mathrm{X} 35$ \\
\hline & - Other parties (NGOs/academics/researchers) & $\mathrm{X} 36$ \\
\hline \multirow{6}{*}{ Networking (X4) } & - Cooperation with the KNP management & $\mathrm{X} 41$ \\
\hline & - Cooperation with local governments & $\mathrm{X} 42$ \\
\hline & - Cooperation with corporations & $\mathrm{X} 43$ \\
\hline & - Interested in organizations in local society & $\mathrm{X} 44$ \\
\hline & - Cooperation with local communities & $\mathrm{X} 45$ \\
\hline & - Leisure interaction with local communities & $\mathrm{X} 46$ \\
\hline \multirow{6}{*}{ Social norm (X5) } & - Knowledge of social norms & $\mathrm{X} 51$ \\
\hline & - Compliance to social norms & $\mathrm{X} 52$ \\
\hline & - Obedience to and implementation of social norms & $\mathrm{X} 53$ \\
\hline & $\begin{array}{l}\text { - Implementation of agreed rules in the community } \\
\text { organization }\end{array}$ & $\mathrm{X} 54$ \\
\hline & - Acknowledgement of and obedience to the KNP rules & $\mathrm{X} 55$ \\
\hline & $\begin{array}{l}\text { - Acknowledgement of and obedience to the local } \\
\text { government rules }\end{array}$ & $\mathrm{X} 56$ \\
\hline \multirow{5}{*}{$\begin{array}{l}\text { Community involvement } \\
\text { (X6) }\end{array}$} & $\begin{array}{l}\text { - Participation in the meetings initiated by the KNP } \\
\text { management }\end{array}$ & X61 \\
\hline & - Participation in the community activities & $\mathrm{X} 62$ \\
\hline & $\begin{array}{l}\text { - Participation in organizations/meetings in local } \\
\text { communities }\end{array}$ & X63 \\
\hline & $\begin{array}{l}\text { - Enthusiasm in criticizing KNP and the local } \\
\text { governments in mangrove management }\end{array}$ & X64 \\
\hline & $\begin{array}{l}\text { - Contribution of ideas to KNP and local governments in } \\
\text { mangrove management }\end{array}$ & X65 \\
\hline \multirow{5}{*}{$\begin{array}{l}\text { Community awareness } \\
\text { (X7) }\end{array}$} & $\begin{array}{l}\text { - Having knowledge that mangrove forests need to be } \\
\text { preserved }\end{array}$ & $\mathrm{X} 71$ \\
\hline & $\begin{array}{l}\text { - Participating in mangrove conservation activities held } \\
\text { by the KNP management }\end{array}$ & $\mathrm{X} 72$ \\
\hline & - Independently doing mangrove conservation activities & $\mathrm{X} 73$ \\
\hline & - Inviting local communities to preserve mangroves & $\mathrm{X} 74$ \\
\hline & $\begin{array}{l}\text { - Having close relationship with local communities in } \\
\text { mangrove conservation }\end{array}$ & $\mathrm{X} 75$ \\
\hline \multirow{5}{*}{$\begin{array}{l}\text { Response to the } \\
\text { utilization of mangrove to } \\
\text { Silvofishery (Y1) }\end{array}$} & - Knowledge of the silvofishery & Y11 \\
\hline & - Knowledge of mangrove utilization & Y12 \\
\hline & - Knowledge of mangrove KNP & Y13 \\
\hline & - Involvement in silvofishery activities or the like & Y14 \\
\hline & - Interest in silvofishery developed in mangrove KNP & Y15 \\
\hline
\end{tabular}

community farms. Wijaya (2011) stated, KNP should immediately arrange the space of the area (zonation) especially in the mangrove area, given the political and demographic problems in the area of KNP.

The degradation of mangrove forest in KNP is caused by the opening of land for ponds and the expansion of the population for various activities including settlements (Mukhlisi \& Gunawan 2016). Forests degradation of mangrove KNP in 2013 is estimated to be approximately 1,845.9 hectares, the damage distribution occurs around Muara Sangatta, Teluk Lombok, and Sangkima (Budiarsa \& Rizal 2013).The main socio-economic challenge to mangrove restoration is land conflicts between communities, KNP, and local government (Gunawan \& Sayektiningsih, 2012). Community-based mangrove management can reduce conflict. In Thailand, standing structures are superior 
Table 2 Summary of socio-economic conditions

\begin{tabular}{lccccc}
\hline Variables & $\begin{array}{c}\text { Singa } \\
\text { Geweh } \\
(\mathrm{n}=180)\end{array}$ & $\begin{array}{c}\text { Kandolo } \\
(\mathrm{n}=60)\end{array}$ & $\begin{array}{c}\text { Teluk } \\
\text { Pandan } \\
(\mathrm{n}=120)\end{array}$ & $\begin{array}{c}\text { Sangkima } \\
(\mathrm{n}=90)\end{array}$ & $\begin{array}{c}\text { Teluk } \\
\text { Singkama } \\
(\mathrm{n}=80)\end{array}$ \\
\hline Gender (\%) & & & & & \\
$\quad$ Men & 71 & 72 & 62 & 66 & 66 \\
$\quad$ Women & 29 & 28 & 38 & 34 & 34 \\
Age group (\%) & & & & & \\
$\quad$ 40 years and below & 67 & 55 & 69 & 44 & 54 \\
$\quad$ 41 years and above & 33 & 45 & 31 & 56 & 46 \\
Education (\%) & 7 & 5 & 3 & 16 & 15 \\
$\quad$ Non formal education & 39 & 40 & 43 & 53 & 50 \\
$\quad$ Elementary school & 33 & 30 & 33 & 16 & 14 \\
$\quad$ Junior high school & 20 & 23 & 19 & 14 & 18 \\
$\quad$ Senior high school & 1 & 2 & 3 & 1 & 4 \\
$\quad$ College/university degree & & & & & \\
Household income (IDR/month) (\%) & 33 & 47 & 58 & 60 & 59 \\
$\quad$ IDR1,000,000 and below & 26 & 27 & 30 & 31 & 25 \\
$\quad$ IDR1,000,000-1,500,000 & 23 & 15 & 8 & 8 & 10 \\
IDR1,500,000-2,000,000 & 13 & 7 & 3 & 1 & 6 \\
IDR2,000,000-4,000,000 & 4 & 5 & 1 & 0 & 0 \\
$\quad$ IDR5,000,000 and above & 42 & 25 & 46 & 46 & 40 \\
Occupation (extraction of mangrove & & & & & \\
resources) (\%) & & & & & \\
\hline
\end{tabular}

$\mathrm{n}=$ number of respondents

to mangrove forests managed by communities rather than in mangrove forests claimed for state management (Sudtongkong \& Webb 2008). KNP in the future should be able to develop like other national parks that have advanced in Indonesia. There are still a weak element of social capital in support of silvofishery but it can still be improved with multi-stakeholder cooperation.

Social capital assesment Assessment of social capital elements are done to find out how strong of social capital that support the utilization of mangrove ecosystem services for silvofishery. Of the seven variables there were 35 questions (indicators) used in this study and theoretically each indicator is related to social capital in the society. Based on the results of the calculation with the scoring method, the social capital has averaged 110.5 and categorized into low category (low: score 82-118). Low scores derive from elements such as levels of education, income levels, awareness and community involvement, while others element were quite high (Table 3 ). So it can be tentatively concluded that the power of social capital was relatively low in order to support the utilization of mangrove ecosystems for silvofishery in Kutai National Park.

The elements of trust, social networks, and social norms in the Singa Geweh Village had lowest score compared to the other four villages. Elements of engagement or participation/proactivity and community awareness of the highest score found in the village of Sangkima. Then the level of education in the Sangkima and Teluk Singkama villages was relatively low compared to the other three villages. The highest income level was found in the Singa Geweh and Kandolo villages. Each element of social capital is not always directly proportional. The study sites show that people with high levels of education and income do not always have high awareness and involvement in the environment or mangrove conservation efforts through the silvofishery system.

The result of scoring method shows that the strength of social capital is still low in the study area. This interpretation needs to be reinforced by other analysis, in this study it was PLS-SEM. Based on the preliminary evaluation for the model measurements, some indicators that do not reflect on the contructs were found. The variable has a factor loading value below 0.5 , so it should be erased in the model for the respecification, so that it meets the feasibility factor of the loading factor above 0.5 . This study used 35 indicators, then there were indicators discarded to improve the validity and reliability. In the analysis for each village, the indicator that was disposed were, in the Singa Geweh Village 16 indicators, Kandolo 12 indicators, Sangkima 5 indicators, Teluk Pandan 12 indicators, and Teluk Singkama 16 indicators. The analysis of all respondents for five villages as many as 11 indicators, were discarded X33, X34, X35, X42, X43, X55, X54, X62, X63, X74, and X75 (Figure 2). After the model was re-specificated, the PLS algorithm results matched the validity and reliability criteria on the measurement model. The Avarage Variance Extracted value was above 0.5 for all sizes and shows that all variables were at various significantly positive correlations. The Composite Reliability analysis results above 0.7 , so it can be stated that the measurement model had been valid and reliable (Table 4).

Strengthening social capital can be proposed to promote sustainable community-based mangrove management 
Table 3 Minimum, maximum, and average values for each variable

\begin{tabular}{|c|c|c|c|}
\hline \multirow{2}{*}{ Variable of social capital } & \multicolumn{2}{|c|}{ Average score } & \multirow{2}{*}{ Average } \\
\hline & Min & $\operatorname{Max}$ & \\
\hline Education level & 2.3 & 2.8 & 2.6 \\
\hline Income level & 1.5 & 2.3 & 1.8 \\
\hline Trust & 16.9 & 22.4 & 20,5 \\
\hline Social networking & 16.6 & 20.8 & 19.3 \\
\hline Social norm & 16.5 & 22.0 & 20.1 \\
\hline Community involvement & 12.5 & 14.9 & 13.9 \\
\hline Community awareness & 12.8 & 17.8 & 14.5 \\
\hline Mangrove services to ecotourism & 13.1 & 14.9 & 17.8 \\
\hline Total score & 92.1 & 117.9 & 110.5 \\
\hline
\end{tabular}

(Qurniati et al. 2017). Social capital is an important ecosystem service, yet humans lack an understanding of how it works, and can be operationalized within the framework of ecosystem services (Barnes et al. 2015). Indicators used for various components of social capital include network, trust, citizen involvement, norms, and values (Bhuiyan \& Hans, 2005). This study has represented several components of social capital that are appropriate to the condition of the study area. Social capital is incomplete if the discussion covers an ecosystem. So that further analysis that relates to all ecosystem components ranging from social capital, mangrove characteristics and the carrying capacity of silvofishery can be a common idea to build a responsible and sustainable model of mangrove utilization.

Interpretation of social capital for silvofishery Social capital owned by individuals or communities is an important resource in an ecosystem that can help improve the quality of ecosystem services. The stronger the social capital, the stronger the community support for sustainable ecosystem services. The social capital in this study is represented by eight variables with $\mathrm{t}$-table significance test $(\alpha 0,05$; $\mathrm{t}$-table 1.96). The results of significance tests for each village show that there were several hypotheses that do not support the use of mangrove forests for silvofishery. For Singa Geweh Village there were four significant variables or supported, namely education, income, awareness and community involvement. For Kandolo Village it was only one significant variable: that is community involvement. For Teluk Pandan Village, there were two variables: awareness and community involvement. For Sangkima Village, there were two variables: namely community awareness, and social norms. And for Teluk Singkama Village, three variables: education, income, and community awareness.

This study aims to investigate the interaction between elements of social capital associated with community perceptions and attitudes toward the utilization of mangrove ecosystem services for silvofishery in coastal areas on KNP, Indonesia. The result of significantcy test for each village's respondents show that there were only one or three of

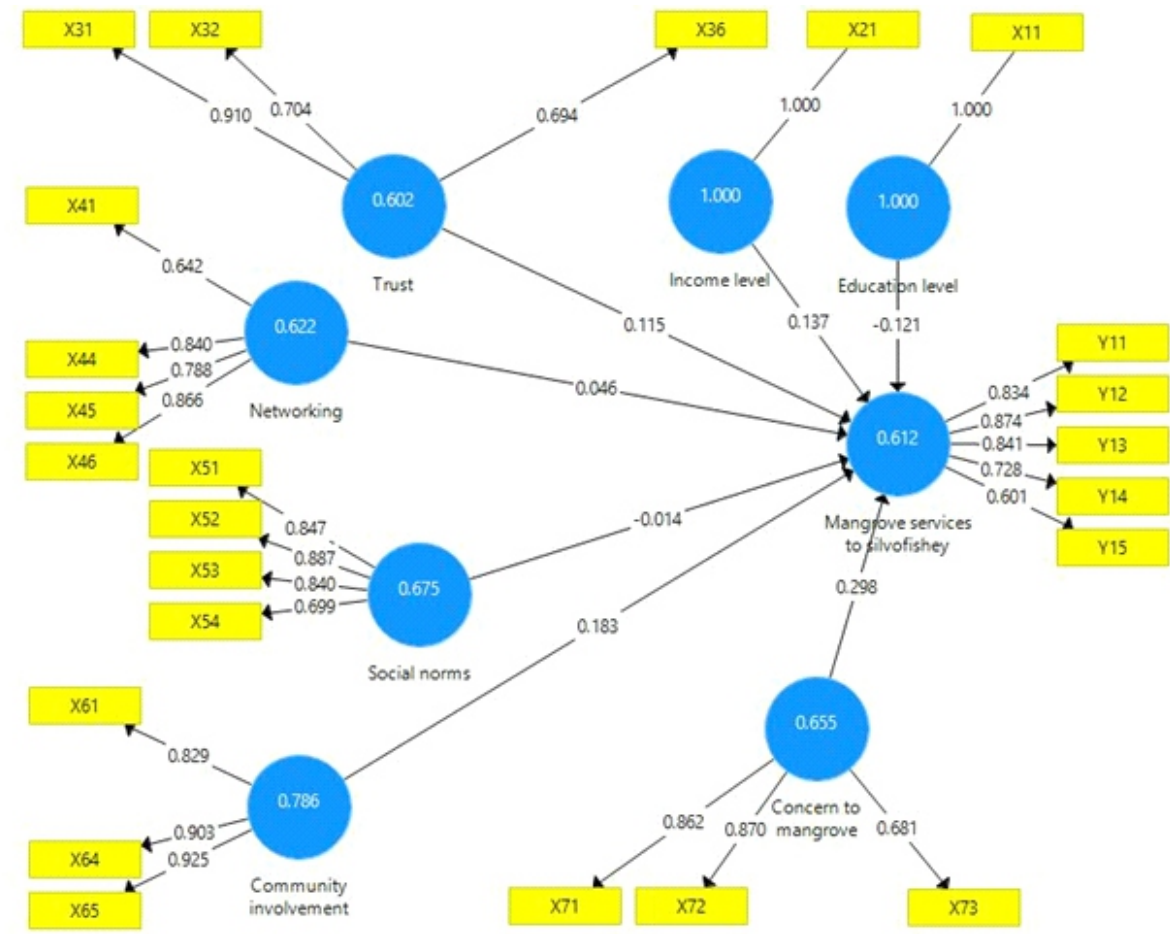

Figure 2 Convergent validity for each loading factor of construct after re-specification. 
Table 4 Assessment of the measurement model (Means, Avarage Variance Extracted $=$ AVE, and Composite Reliability $=$ CR $)$

\begin{tabular}{ccccccccccccccc}
\hline \multirow{2}{*}{$\begin{array}{c}\text { Laten } \\
\text { variable }\end{array}$} & \multicolumn{1}{c}{ Village } & Singa Geweh & \multicolumn{1}{c}{ Kandolo } & \multicolumn{1}{c}{$\begin{array}{c}\text { Teluk } \\
\text { Pandan }\end{array}$} & \multicolumn{1}{c}{ Sangkima } & \multicolumn{4}{c}{$\begin{array}{c}\text { Teluk } \\
\text { Singkama }\end{array}$} & \multicolumn{2}{c}{$\begin{array}{c}\text { Respondent } \\
(\mathrm{n}=530)\end{array}$} \\
\cline { 2 - 16 } & AVE & CR & AVE & CR & AVE & CR & AVE & CR & AVE & CR & AVE & CR \\
\hline (X1) & 1.00 & 1.00 & 1.00 & 1.00 & 1.00 & 1.00 & 1.00 & 1.00 & 1.00 & 1.00 & 1.00 & 1.00 \\
(X2) & 1.00 & 1.00 & 1.00 & 1.00 & 1.00 & 1.00 & 1.00 & 1.00 & 1.00 & 1.00 & 1.00 & 1.00 \\
(X3) & 0.82 & 0.69 & 0.69 & 0.87 & 0.78 & 0.66 & 0.90 & 0.75 & 0.81 & 0.68 & 0.82 & 0.60 \\
(X4) & 1.00 & 1.00 & 0.73 & 0.89 & 0.94 & 0.85 & 0.86 & 0.51 & 0.86 & 0.75 & 0.87 & 0.62 \\
(X5) & 0.89 & 0.67 & 0.78 & 0.91 & 0.87 & 0.64 & 0.88 & 0.55 & 0.83 & 0.71 & 0.89 & 0.67 \\
(X6) & 0.92 & 0.79 & 0.74 & 0.92 & 0.89 & 0.67 & 0.89 & 0.68 & 0.84 & 0.63 & 0.92 & 0.79 \\
(X7) & 0.91 & 0.84 & 0.65 & 0.84 & 0.83 & 0.62 & 0.83 & 0.55 & 0.83 & 0.62 & 0.85 & 0.65 \\
(Y1) & 0.90 & 0.65 & 0.67 & 0.91 & 0.87 & 0.63 & 0.91 & 0.73 & 0.89 & 0.62 & 0.89 & 0.61 \\
\hline
\end{tabular}

*) according to rule of thumb (AVE $>0.5 ; \mathrm{CR}>0.7)$; number of respondents (n), Education level (X1); Income level (X2); Trust (X3); Networking (X4); Social norm (X5); Community involvement (X6); Community awareness (X7); Response to the utilization of Mangrove to Silvofishery (Y1).

Table 5 Significant test results after re-specification to 530 respondents

\begin{tabular}{lccl}
\hline & \multicolumn{2}{c}{ Results } \\
\cline { 2 - 4 } Hypothesis of latent variables & $\begin{array}{c}\text { Path } \\
\text { coefficients }\end{array}$ & t-Value & Supported \\
\hline Community involvement & 0.183 & 3.317 & Significant \\
Community awareness & 0.298 & 5.990 & Significant \\
Education level & -0.121 & 2.808 & Significant \\
Income level & 0.137 & 3.112 & Significant \\
Social networking & 0.046 & 0.814 & Not significant \\
Social norm & -0.014 & 0.281 & Not significant \\
Trust & 0.115 & 2.191 & Significant \\
\hline
\end{tabular}

variables was significant. At the end result significant test for all respondents in five villages showed there were five significant variables (t-Value above t-table 1.96) (Table 6). Two variables that have not been supported were social networks that also do not support for significant test results in five villages. The other was the social norm, which only supported in the Sangkima Village, in while the other four villages were not supported.

Sylvofishery cultivation of mangrove crabs can be an alternative livelihood for community survival. The analysis of sustainability of economic dimension show that sylvofishery management of mangrove crab was sustainable with index value of $76.4 \%$ (Wijaya 2011). The area of land with a very suitable potential for the development of silvofishery of mangrove crab in Berau District of East Kalimantan was 12,685 hectare, the potential was 20,806 ha, and the unsuitable was 46,718 hectare (Setiawan \& Triyanto 2012). Silvofishery technique was perfect for communitybased mangrove conservation efforts. One hectare of fish ponds in natural mangrove forests will produce fish and shrimp as much as $287 \mathrm{~kg}$ year ${ }^{-1}$, but the loss of one hectare of mangrove forest results in the loss of fish and shrimp up to $480 \mathrm{~kg}$ year $^{-1}$ (Anwar \& Gunawan 2006). Although one of the goals of silvofishery is to increase the income of local communities, conservation of mangrove forests should be considered in depth (Takashima 2000). Reviewing protected area models, greater participation, recognizing the value of protected areas and stronger institutional support, and a respected community component will be needed to maintain protected areas in the next decades (IUCN WCPA2017).

Diversity and abundance of mangrove species can affect nutrition levels, especially nitrogen in ponds of silvofishery system in Semarang, Indonesia (Hastuti \& Budihastuti 2017). In order to withstand the rate of degradation of mangrove forests, proper silvofishery effort is required (Budihastuti et al. 2012). Utilization of mangroves for silvofishery can bring benefits to the local community, it should be developed for optimal and sustainable results (Poedjirahayoe 2015). Involving local communities in mangrove management is an effective way to maintain and improve the function of protecting mangrove forests and at the some time providing livelihood for local communities (Schmitt \& Norman 2015). Community participation is needed for the conservation and development of mangrove forest conservation areas (Suprakto et al. 2014). The pattern of consolidation between utilization and conservation in mangrove forest has been introduced under the name silvofishery in Indonesia, this pattern is also called "tumpang 
sari" where it is possible to raise aquatic animals and mangrove trees on the same land (Takashima 2000).

PLS-SEM has been widely used for data analysis (Sözbilir 2018). PLS-SEM is a second-generation statistical method (Hair et al. 2014), which is suitable for large and small sample sizes and is considered a reasonable choice for data analysis models and validating predictive models (Chin, 2010). PLS deals with Principal Components Analysis (PCA), and allows for information about the relationship between predictive and targeted variables (Bryce et al. 2016). The social capital research using PLS-SEM method is the assessment of social capital of agribusiness actors in Bogor, Indonesia (Mursid et al. 2018). Research with PLS-SEM method has also been done to know the interaction between social capital, creativity and organizational efficiency (Sözbilir 2018). Research related to other social capital, namely the assessment of social capital resources in adapting coastal cities of East Africa to climate change (Kithiia 2010). The topic of social capital has gained much attention from social researchers around the world, especially in the perspective of collective action (Aswin et al.2017).

Research on social capital in mangrove area has also been studied with the result of social capital level is low in community group in two villages on Labuhan Maringgai District, East Lampung Regency, Indonesia (Juita et al. 2016). The level of awareness and community participation is relatively low in mangrove management in a case study in Lampung province, Indonesia (Qurniati et al. 2017). Adequacy of social capital that was low has been founded in social capital studies in KNP buffer zones for ecotourism by SCAT and Confirmatory Factor Analysis (CFA) methods (Oktadiayani et al. 2013). Furthermore, the results of the analysis with the PLS-SEM method proved that in each study village, not all social capital elements support for silvofishery. Overall analysis of respondents also shows there were still two social capital that had not supported or still weak, namely social networks and social norms. Hartoyo (2012) stated that efforts to conserve mangrove forests are associated with the strengthening of social capital. Strengthening networks, trusts, values and social norms, both in horizontal and vertical networks should be more nurtured, mentored technically and accompanied by nongovernmental organizations (NGOs). According to Radnitz et al. (2009) explained, the level of social capital observed tends to vary, depending on the context. In the less repressive state conditions and public contacts with larger NGOs can increase the network in the community higher, while the more repressive state tends to increase norms and trust in the community. Grootaert and van Bastelaer (2001) stated,the successful community-based development relies heavily on the utilization of social capital. Institutional reforms of state institutions, social institutions and inclusive decentralization should be able to bring services closer to the poor in order to increase social capital. Without social capital, society will generally collapse. There is growing empirical evidence that social capital contributes significantly to sustainable development.

\section{Conclusion}

The assessment of social capital by scoring showing an average score of 110.5 (low category). This low value acquisition had been further proven by analysis using PLSSEM. The results of the analysis have proved that there were several elements of social capital in each village that were still not supported, especially support for the utilization of mangrove with silvofishery system. Significant test for all respondents in five villages indicated that there were five significant or supported variables ( $t$-Values above t-Table 1.96) i.e. education level, income level, community awareness, community involvement, and trust. Two other variables were yet supported (social networks and social norms). Both elements are important as information of socioeconomic conditions but should not be used as latent variables in similar studies. The stronger of the social capital, the better community's support for ecosystem services. The strength of social capital observed in this study tends to vary. Social capital was weak in the study area, whereas the power of social capital is expected to realize conservation-based economic development. The weak social capital challenges the KNP management unit, local government, and NGOs to build a concept of social capital development and create an environment that can support the strengthening of social capital in the community. Silvofishery program in conservation area should get a special attention and become a program to strengthen social capital of society which finally realize well-being of society around KNP.

\section{Acknowledgements}

Authors would like to thank the KNP management unit that has supported and provided an opportunity to conduct this research. Acknowledgments are also conveyed to the lecturers and students of STIPER Kutai Timur in Sangatta, East Kalimantan who were very helpful in the field research. Thank you also to the Ministry of Research, Technology and Higher Education of the Republic of Indonesia (the Directorate General of Research and Development) which has encouraged the improvement of the quality and quantity of research results by providing research assistance and incentives for authors.

\section{References}

Asmin F, Darusman D, Ichwandi I, Suharjito D. 2017. Social capital of parak and rimbo management in West Sumatera. Jurnal Manajemen Hutan Tropika 23(3):140-149. https://doi.org/10.7226/jtfm.23.3.140

Anwar C, Gunawan H. 2006. Peranan Ekologis dan Sosial Ekonomis Hutan Mangrove dalam Mendukung Pembangunan Wilayah Pesisir. Makalah Utama pada Ekspose Hasil-hasil Penelitian: Konservasi dan Rehabilitasi Sumberdaya Hutan. Padang, 20 September 2006. 23-34.

Barnes-Mauthe M, Kirsten LLO, Luke MB, Bienvenue Z, 
Thomas AO, Pietervan B. 2015. Social capital as an ecosystem service: Evidence from a locally managed marine area. Ecosystem Services 16:283-293. https://doi.org//10.1016/j.ecoser.2014.10.009

Budiarsa AA, Rizal S. 2013. Pemetaan dan analisis tingkat kerusakan hutan mangrove di Taman Nasional Kutai berdasarkan data citra setelit Landsat ETM dan kerapatan vegetasi. Jurnal Ilmu Perikanan Tropis 19(1):54-61.

Brander LM, Wagtendonk AJ, Hussain SS, McVittie A, Verburg PH, de Groot RS, van der Ploeg S. 2012. Ecosystem service values for mangroves in Southeast Asia: A meta-analysis and value transfer application. Ecosystem Services 1:62-69. https://doi.org//10.1016/ j.ecoser.2012.06.003.

Bryce R, Irvine KN, Church A, Fish R, Ranger S, Kenter JO. 2016. Subjective well-being indicators for large-scale assessment of cultural ecosystem services. Ecosystem Services 21:258-269. https://doi.org//10.1016/ j.ecoser.2016.07.015.

Budihastuti, Anggoro RS, Saputra SW. 2012. The application of silvofishery on tilapia (Oreochromis niloticus) and milkfish (Chanos chanos) fattening within mangrove ecosystem og the Northern Coastal area of Semarang Citu. Journal of Coastal Development 16(1):89-93. https://doi.org/10.7454/mss.v21i4. 6475.

Burt RS. 1992. Excerpt from The Sosial Structure of Competition, in Structure Holes: The Social Structure of Competition. Cambridge, London.

Castellan CM. 2010. Quantitative and qualitative research: A View for Clarity. International Journal of Education 2(2):1-14.

Eddy S, Ridho MR, Iskandar I, Mulyana A. 2016. Community-based mangrove forests concervation for sustainable fisheries. Jurnal Silvikultur Tropika. 07(3):43-47.

Fukuyama F. 2000. Social capital and civil society. International Monetary Fund Working Paper, $\mathrm{WP} / 00 / 74$

Grootaert C, van Bastelaer T. 2001. Understanding and measuring social capital: A synthesis of findings and recommendations from the social capital initiative. The World Bank. Social Development Department. Social Capital Working Paper Series, Washington, DC.

Grootaert C, Narayan D, Jones VN, Woolcock M. 2003 Measuring social capital: An integrated questionnaire. The world bank. social development family, environmentally and socially, sustainable development network, Washington, DC.

Hair JF, Hult GTM, Ringle CM, Sarstedt M. 2014. A Primer on Partial Least Squares Structural Equation Modeling (PLS-SEM). Los Angeles: Sage, Thousand Oak.

Hartoyo, Rochana E, Wirawan B. 2012. Penguatan Modal Sosial dalam Pelestarian Hutan Mangrove di Pulau Pahawang, Kecamatan Punduh Pidada, Kabupaten Pesawaran. Seminar Hasil-Hasil Penelitian dan Pengabdian Kepada Masyarakat-Dies Natalis FISIP Unila, Lampung.

Hastuti ED, Budihastuti R. 2017. Nutrient accumulation in the sediment of silvofishery ponds in Semarang. Makara Journal of Science 21(4):195-201. https://doi.org/10.7454/mss.v21i4.6475.

IUCN WCPA. 2017. PARKS: The international journal of protected areas and conservation. IUCN World Commissionon Protected Areas (WCPA). 23(1), Gland, Switzerland: IUCN.

Juita K, Nababan, Qurniati R, Kustanti A, 2016. Modal sosial pada pengelolaan dan pelestarian hutan mangrove di Kecamatan Labuhan Maringgai Kabupaten Lampung Timur. Jurnal Silva Lestari 4 (2):89-100.

Kithiia J. 2010. Old notion-new relevance: Setting the stage for the use of social capital resource in adapting East African coastal cities to climate change. International Journal of Urban Sustainable Development 1(1-2)17-32. https://doi.org/10.1080/1946313100 3607630

Kunarso A, Tubagus AA, Syabana, Azwar F, Bastoni. 2015. Mangrove rehabilitation using silvofishery system in Telang Protection Forest, South Sumatra: Opportunities and challenges. Proceedings: The International Conference of Indonesia Forestry Researchers III. Bogor, 21-22 October 2015.

Lee SY, Primavera JH, Guebas FD, McKee K, Bosire JO, Cannicci S, Diele K, Fromard F, Koedam N, Marchand C, Mendelssohn I, Mukherjee N, Record S. 2014. Ecological role and services of tropical mangrove ecosystems: a reassessment. Global Ecology and Biogeography. 23:726 -743. https://doi.org/10.1111/ geb.12155.

Luck DJ, Taylor WG, Robin. 1987. Marketing Research. Eaglewood: Prentice Hall.

Miguel A, Piqueras C, Trinogga J, Grande C, Minden V, Maier M, Kleyer M. 2017. Interactions between ecosystem properties and land use clarify spatial strategies to optimize trade-offs between agriculture and species conservation. International Journal of Biodiversity Science, Ecosystem Services \& 
Management 13(2):53-66. https://doi.org/10.1080/ 21513732.2017 .1289245 .

Oktadiyani P, Muntasib EKSH, Sunkar A. 2013. Modal sosial masyarakat di kawasan penyangga Taman Nasional Kutai (TNK) dalam pengembangan ekowisata. Jurnal Media Konservasi 18 (1):1-9.

Poedjirahajoe E. 2011. Potensi ekosistem hutan mangrove untuk pengembangan silvofishery di Taman Nasional Alas Purwo. Prosiding: Forum Nasional Pemacuan Sumber Daya Ikan III, Yogyakarta: Fakultas Kehutanan Universitas Gadjah Mada.

Poedjirahajoe E. 2015. Klasifikasi habitat mangrove untuk pengembangan silvofishery kepiting soka (Scylla serrata) di Pantai Utara Kabupaten Rembang. Jurnal Ilmu Kehutanan 9(2):86-93.

Pretty J, Ward H. 2001. Social capital and the environment. World Development 29(2):209-227.

Purwiyanto AIS, Agustriani F. 2014. Effect of silvofishery on ponds nutrient levels. Jurnal Ilmu Kelautan 19(2):81-87.

Qurniati R, Wahyu H, Hari K, Firdasari, Makoto I. 2017. Social capital in mangrove management: A case study in Lampung Province, Indonesia. Journal of Forest and Environmental Science 33(1):8-21. https://doi.org/10.7747/JFES.2017.33.1.8.

Radnitz, Wheatley SJ, and Zürcher C. 2009. The origins of social capital: Evidence from a survey of post-soviet Central Asia. Comparative Political Studies. SAGE journal 42(6):707-732 https://doi.org/10.1177/ 0010414008329893 .

Setiawan F, Triyanto. 2012. Studi kesesuaian lahan untuk pengembangan silvofishery kepiting bakau (Scylla serrata) di Kabupaten Berau, Kalimantan Timur. LIMNOTEK 19(2):158-165

Sayektiningsih T, Gunawan W. 2012. Kondisi sosial ekonomi masyarakat di sekitar hutan mangrove Taman Nasional Kutai, Kalimantan Timur. Prosiding: Seminar hasil-hasil penelitian BPTKSDA Samboja, Balai Penelitian Teknologi Konservasi Sumber Daya Alam, Samboja.

Siswanto W. 2017. Pengelolaan kawasan konservasi di Indonesia. Kerjasama Forests and Climate Change Programmed dan Kementerian Lingkungan Hidup dan Kehutanan. Deutsche Gesellschaft für Internationale Zusammenarbeit (GIZ) GmbH. Bonn and Eschborn, Germany.

Sözbilir F. 2018. The interaction between social capital, creativity and efficiency in organizations. Thinking Skills and Creativity 27:92-100. https://doi.org/ 10.1016/j.tsc.2017.12.006.

Sulistyorini IS, Poedjirahajoe E, Edwin M, Imanuddin. 2017. Potensi ekosistem mangrove untuk pengembangan silvofishery di Taman Nasional Kutai, Kalimantan Timur. Jurnal AGRIFOR 16(2):209-218.

Takashima F. 2000. Silvofishery: an aquaculture system harmonized with environment. SEAFDEC/AQD Institutional Repository (SAIR). Proceedings: The Workshop on Mangrove-Friendly Aquaculture organized by the SEAFDEC Aquaculture Department. Iloilo City, Philippines January 11-15, 1999

Tobing ISL. 2008. Manajemen kawasan dalam upaya konservasi sumberdaya alam hayati. Vis Vitalis 01(2):63-70.

Walters BB. 2004. Local management of mangrove forests in the Philippines: Successful conservation or efficient resource exploitation? Human Ecology Journal 32(2):177-195.

Wijaya NI. 2011. Pengelolaan zona pemanfaatan ekosistem mangrove melalui optimasi pemanfaatan sumberdaya kepiting Bakau (Scylla serrata) di Taman Nasional Kutai Provinsi Kalimantan Timur [disertation] Bogor: Bogor Agricultural University. 